\title{
LESS IS MORE? PROTECTING DATABASES IN THE EU AFTER RYANAIR*
}

\author{
by \\ MATĚJ MYŠKA**, JAKUB HARAŠTA**
}

This paper discusses the current status quo of legal protection of databases after the Ryanair case (C-30/14). The first part focuses on the subject matter, scope and limits of legal protection for databases according to the Directive 96/9/EC and the related relevant Court of Justice of the European Union case law. Next, it briefly discusses further possibilities of protection for databases not protected by the copyright and/or sui generis database rights. The second part analyses the recent decision of the Court of Justice of the European Union in the case Ryanair (C-30/14). The third part then discusses the consequences of this decision as regards to potential monopolization of synthetic data by contract. The conclusions are summed up in the final fourth part.

\section{KEY WORDS}

Database Protection, Copyright, Sui Generis Database Rights, Exceptions and Limitations, Contract Law, Ryanair Case, C-30/14, Directive 96/9/EC

\footnotetext{
The publication of this paper is supported by the Czech Science Foundation - project Legal Framework for Collecting, Processing, Storing and Utilizing of Research Data - registration no. GA15-20763S.

The authors would like to kindly thank the anonymous reviewers for their valuable input provided in the reviews. Earlier versions of this paper were presented at the VII. national conference České právo a informační a technologie (24. - 23. 9. 2015, Brno, Czech Republic), the $4^{\text {th }}$ Göttingen International Research Forum on Law and ICT/IP 2015 (5. - 6. 11. 2015, Göttingen, Germany) and $13^{\text {th }}$ international conference Cyberspace (25. - 26. 11. 2016, Brno, Czech Republic). In particular, we would like to express our gratitude to prof. Andreas Wiebe, prof. Radim Polčák, Dr. Clemens Appl, Dr. Roman Heidinger, Dr. Leonhard Reis, Dr. Pavel Koukal and Talya Ponchek for their helpful comments and fruitful discussion.

* matej.myska@law.muni.cz, assistant professor at the Institute of Law and Technology in Masaryk University Brno

*** jakub.harasta@law.muni.cz, assistant and Ph.D. student at the Institute of Law and Technology in Masaryk University Brno.
} 


\section{INTRODUCTION}

The recent decision of the Court of Justice of the European Union ("CJEU") in the Ryanair case again opened the much-debated question ${ }^{1}$ of the scope of protection for databases under the directive 96/9/EC. ${ }^{2}$ Basically, the CJEU stated that databases not meeting the threshold required for obtaining copyright and/or sui generis rights protection are at the full contractual disposal of the database manager, ${ }^{3}$ subject only to the limits posed by applicable national law. Consequently, as no legal protection exists, no exceptions are applicable and the person disposing with the database is prima facie more protected than a database author or a maker of the database. ${ }^{4}$

In our opinion, with this judgment, the CJEU opened a new chapter of protecting databases. To fully understand the possible outcomes and to demonstrate the rather paradoxical consequences we first provide

1 See e.g.: DAVISON, Mark J. The Legal Protection of Databases. Cambridge: Cambridge University Press, 2003.;

BEUNEN, Annemarie Christiane. Protection for databases The European Database Directive and its effects in the Netherlands, France and the United Kingdom [online]. Nijmegen: Wolf Legal Publishers, Nijmegen E.M. Meijers Institute of Legal Studies, Faculty of Law, Leiden University, 2007. Series of the E.M. Meijers Institute of Legal Studies of Leiden University, 125.;

DERCLAYE, Estelle. The Legal Protection of Databases A Comparative Analysis. Cheltenham, UK; Northampton, MA: Edward Elgar, 2008.;

HERR, Robin Elizabeth. Is the Sui Generis Right a Failed Experiment: A Legal and Theoretical Exploration of How to Regulate Unoriginal Database Contents and Possible Suggestions for Reform. Copenhagen: DJØF Pub., 2008.;

HUGENHOLTZ, P. Bernt. Database Directive. In: DREIER, Thomas et al. (eds.). Concise European Copyright Law. Alphen aan den Rijn: Kluwer Law International, 2006.;

LEWINSKI, Silke von. Database Directive. In: WALTER, Michel M.; LEWINSKI, Silke von (eds.). European Copyright Law: A Commentary. Oxford; New York: Oxford University Press, 2010;;

DERCLAYE, Estelle. Database Directive. In: STAMATOUDI, Irini A.; TORREMANS, Paul (eds.). EU Copyright Law: A Commentary. Cheltenham: Edward Elgar, 2014.;

GROSHEIDE, F. Willem. SUI Generis Protection for Databases the European way: An Analysis. International Intellectual Property Law \& Policy. 2000, Vol. 4.;

TROSOW, Samuel E. Sui Generis Database Legislation: A Critical Analysis. Yale Journal of Law and Technology. 2004, Vol. 7, Nr. 2.

2 Directive of the European Parliament and Council 96/9/EC of 11 March 1996 on the legal protection of databases. In EUR-Lex [Legal Information System]. Publications Office of the European Union.

http://eur-lex.europa.eu/LexUriServ/LexUriServ.do?uri=CELEX:31996L0009:CS:HTML.

Further referred as "Directive". All references to articles or recitals without mentioning any legal instrument are referring to the Directive.

3 As no rights are vested in this person, the term author/maker used in the Directive is not appropriate - therefore we use the neutral term "manager" as denomination for the person that has merely produced and amassed the data.

4 As there are no existing rights that could be infringed, i.e. no acts need to be exempted from liability. 
for a brief overview of the current state of the legal protection of databases as clarified by the CJEU. The first part thereof thus focuses on the concept of database, possibilities and prerequisites for its legal protection and in particular uncertainties and gaps in the interpretation of the Directive as provided by the CJEU. ${ }^{5}$ This part also briefly discusses further possibilities of protection for databases not protected by the regimes offered by the Directive. The second part analyses the recent decision of the CJEU in the Ryanair ${ }^{6}$ case in relation to the protection regimes discussed in the previous part. The third part explores its consequences and discusses whether it enables potential monopolization of data available from sole-source databases by contract. The conclusions are then summed up in the final part.

\section{LEGAL PROTECTION OF DATABASES AND RELATED CJEU CASE LAW}

Since the Directive became effective, the CJEU has had the opportunity to clarify its rather opaque provisions in mere twelve cases. ${ }^{7}$ The conceptual difficulties stem from the two-tier system of protection of databases introduced by the Directive, namely the copyright and sui generis rights. Although the protection regimes differ in the object of protection, they may cumulate $^{8}$ and could be potentially held by multiple entities. ${ }^{9}$ These regimes are also "stackable" with other types of protection, ${ }^{10}$ as will be shown later in this paper. On the other hand, the two tiers of protection are not dependent or pre-requiring, i.e. sui generis rights are granted even without fulfilling the requirements for copyright protection and vice versa (Art. 7(4)).

5 However, it is not our aim to discuss the general issues of legal protection of databases or provide an introduction to this topic. For detailed discussion of these general issues see e.g. the sources cited supra in the footnote 1.

6 Ryanair, C-30/14, ECLI:EU:C:2015:10.

7 Up until submission of the final version of this paper, i.e. 30. 8. 2016. See the overview available from: celex.lawportal.cz.

8 QUAEDVLIEG, Antoon. Overlap/relationships between copyright and other intellectual property rights. In: DERCLAYE, Estelle (ed.). Research Handbook on the Future of EU Copyright. Cheltenham, UK: Northampton, MA: Edward Elgar, 2009, p. 483.

9 On the issues of multiplicity of rightholders in case of databases see e.g.: MYŠKA, Matěj; KOŠČÍK, Michal. Controlling Data in Networked Research. In: Internationales Rechtsinformatik Symposion: Tagungsband des 19. Internationales Rechtsinformatik Symposions. Salzburg: Österreichische Computer Gesellschaft, 2016.

10 Database Directive. In: STAMATOUDI, Irini A.; TORREMANS, Paul (eds.). EU Copyright Law: A Commentary. Cheltenham: Edward Elgar, 2014, p. 323. 
As will be discussed in detail below the CJEU gradually defined and refined the term "database", dealt with the issue of the copyright protection of databases and delimited the scope of the respective sui generis rights. After developing the consistent line of case law on what could be protected, the case law focused on the limits of the protection and on the question of whether these are also applicable on mere unprotected databases.

\subsection{THE TERM "DATABASE"}

Certain basic conceptual features enumerated in the Art. 1(2) must be fulfilled in order to consider a collection of data a database. According to this article it must be a

"collection of independent works, data or other materials arranged in a systematic or methodical way and individually accessible by electronic or other means."

As observed by Derclaye the CJEU has already interpreted most of the terms used in the second paragraph of the first article of the Directive. ${ }^{11}$ Generally, the term "database" must be given a wide scope

"unencumbered by considerations of a formal, technical or material nature". ${ }^{12}$

Further, the concept of "database" is "specifically defined in terms of its function". ${ }^{13}$ The CJEU further clarified the criterion of independence of the data contained in the database as follows:

"materials which are separable from one another without their informative, literary, artistic, musical or other value being affected". ${ }^{14}$

Furthermore, the data contained within the database or even extracted thereof must have autonomous information value. However, as critically

11 DERCLAYE, Estelle. Database Directive. In: STAMATOUDI, Irini A.; TORREMANS, Paul (eds.). EU Copyright Law: A Commentary. Cheltenham: Edward Elgar, 2014, p. 300.

12 OPAP, C-444/02, ECLI:EU:C:2004:697, para. 20; also Ryanair, C-30/14, ECLI:EU:C:2015:10, para. 2.

13 Verlag Esterbauer, C-490/14, ECLI:EU:C:2015:735, para. 16 (referring to OPAP, C-444/02, EU:C:2004:697, para. 27).

14 OPAP, C-444/02, ECLI:EU:C:2004:697, para. 29. 
observed by Synodinou, ${ }^{15}$ this criterion has been somewhat alleviated in the Verlag Esterbauer case. ${ }^{16}$ According to the CJEU this criterion is to be evaluated subjectively, i.e. from the perspective of the party interested in the extracted material. ${ }^{17}$ In the Ryanair case the CJEU also clarified that this definition was intended for the purposes of the Directive only. The very fact that the database meets all of these criteria does not per se establish the applicability of the general provisions for the forms of legal protection discussed below (Art. 5 and 7), or subsequently the provision on limitations and exceptions. $^{18}$

\subsection{COPYRIGHT PROTECTION AND ITS LIMITATION}

Copyright protection according to the Art. 3(1) applies to databases which,

"by reason of the selection or arrangement of their contents, constitute the author's own intellectual creation".

Consequently, a database must have contents to express the required originality in its selection or arrangement. ${ }^{19}$ The criterion of originality is fulfilled when the author of the database

"expresses his creative ability in an original manner by making free and creative choices". ${ }^{20}$

In the Football Dataco case the CJEU reiterated that no other criterion should be allowed for granting of database protection. ${ }^{21}$ Especially in the case of electronic databases, it is often disputed what exactly should

15 SYNODINOU, Tatiana. 20 years after the birth of the Database Directive, still mapping EU database law... Kluwer Copyright Blog [online]. 15. 12. 2015 [cit. 30. 8. 2016].

16 Verlag Esterbauer, C-490/14, ECLI:EU:C:2015:735.

17 Ibid., para. 27.

18 Ryanair, C-30/14, ECLI:EU:C:2015:10, para. 34.

19 BEUNEN, Annemarie Christiane. Protection for databases The European Database Directive and its effects in the Netherlands, France and the United Kingdom [online]. Nijmegen: Wolf Legal Publishers, Nijmegen E.M. Meijers Institute of Legal Studies, Faculty of Law, Leiden University, 2007, p. 25.

20 Footbal Dataco, C-604/10, ECLI:EU:C:2012:115, para. 38. (Referring by analogy to: Infopaq International, C-5/08, ECLI:EU:C:2009:465, para. 45; Bezpečnostní softwarová asociace, C-393/09, ECLI:EU:C:2010:816, para. 50; and Painer, C-145/10, ECLI:EU:C:2011:798, para. 89).

21 Footbal Dataco, C-604/10, ECLI:EU:C:2012:115, para. 40. As regards to copyright protection, the Directive itself does not prohibit Member States to award protection for "creative databases" that constitute a protected work, as it is the case for example in the Czech Republic. According to $\S 2(5)$ of the Czech Copyright Act such databases are protected as collections. (Act 121/2000 Sb., Copyright Code. Unofficial and not up-to-date English translation available online:

http://www.mkcr.cz/assets/autorske-pravo/Act_no_121_2000.doc.). 
the object of copyright protection be. ${ }^{22}$ Already in 2007 Beunen sceptically claimed that protection by copyright

"will only be of limited importance for databases". ${ }^{23}$

As observed by Rieger, the subject matter should thus be the conceptual model of database that is expressed in the metadata and contains the logic overview of all the data contained in the collection and its interlinkages. ${ }^{24}$

The creator of such a database is granted the exclusive rights to restrict reproduction, adaptation, distribution, and communication to the public of the whole or parts of the structure of the database. Pursuant to the recital 33 the right of distribution does not exhaust in on-line databases, i.e. the conclusions of the CJEU reached in the UsedSoft ${ }^{25}$ case are not applicable per analogiam. On the other hand Derclaye applies the conclusion of the CJEU in the The British Horseracing Board and Others case ${ }^{26}$ on the act of consultation of an electronic database and considers it a restricted one. ${ }^{27}$ The reason for this deduction is the inevitable making of a temporary reproduction in the process (Art. 5 letter a).

As regards to exceptions, which are of particular importance in the context of this paper, the Directive provides for one mandatory exception and three optional ones (use for private purposes of a nonelectronic database; illustration for teaching or scientific research, public security/administrative or judicial procedure reasons). The mandatory exception covers the access to the contents and normal use thereof by the lawful user. Such protection aims to balance the rights of the author and users and should prevent protection of sole data. Again, it is not undisputed how the term "lawful user" should be defined. Walter and von Lewinski consider the lawfulness to be established, when the user uses the database with the consent of the rightholder or

22 RIEGER, Sören. Der rechtliche Schutz wissenschaftlicher Datenbanken. Tübingen: Mohr Siebeck, 2010, p. 98.

23 BEUNEN, Annemarie Christiane. Protection for databases The European Database Directive and its effects in the Netherlands, France and the United Kingdom [online]. Nijmegen: Wolf Legal Publishers, Nijmegen E.M. Meijers Institute of Legal Studies, Faculty of Law, Leiden University, 2007, p. 77.

24 RIEGER, Sören. Der rechtliche Schutz wissenschaftlicher Datenbanken. Tübingen: Mohr Siebeck, 2010, p. 99 and sources cited in the footnote 19 therein.

25 UsedSoft, C-128/11, ECLI:EU:C:2012:407.

26 The British Horseracing Board and Others, ECLI:EU:C:2004:695, C-203/02, paras. 54-55.

27 DERCLAYE, Estelle. Database Directive. In: STAMATOUDI, Irini A.; TORREMANS, Paul (eds.). EU Copyright Law: A Commentary. Cheltenham: Edward Elgar, 2014, p. 313. 
"on the basis of acts permitted by law through limitations and exceptions". ${ }^{28}$

Based on the UsedSoft case ratio Derclaye on the other hand claims that the lawfulness could be based on acts and contracts other than license, e.g. public lending, gift, sale, re-sale. ${ }^{29}$ This specific exception must not be overridden by contract - any such contractual arrangements are null and void (Art. 15).

All of the abovementioned exceptions are subject to the so-called three-step test. Consequently, any interpretation that will allow use which would unreasonably prejudice the legitimate interests of the rightholder or conflict with normal exploitation of the database is prohibited. Interestingly, the Art. 6 does not request the authorized making of the database available to the public. Beunen however relies on the general principle of the copyright law, that the exceptions and limitations are applicable only after lawful publication of a protected work. ${ }^{30}$

\subsection{SUI GENERIS DATABASE RIGHTS PROTECTION, SUBSTANTIAL INVESTMENT AND LIMITATION THEREOF}

The Directive introduced a new level for protection for amassed data. However, the subject matter of protection as such is not precisely defined and could be interpreted differently. Rieger points out that the investment, even though being a base for granting of rights, cannot be protected as subject matter as it is only a one-time occurrence. ${ }^{31}$ Thus the sui generis rights should protect the "ideal intangible good of the database", 32 not the content itself.

The granted rights of extraction and re-utilization are in their core similar to the copyright rights of reproduction and communication to the public. ${ }^{33}$ These rights must be interpreted widely, as the CJEU noted

${ }^{28}$ LEWINSKI, Silke von. Database Directive. In: WALTER, Michel M.; LEWINSKI, Silke von (eds.). European Copyright Law: A Commentary. Oxford; New York: Oxford University Press, 2010, p. 727.

29 DERCLAYE, Estelle. Database Directive. In: STAMATOUDI, Irini A.; TORREMANS, Paul (eds.). EU Copyright Law: A Commentary. Cheltenham: Edward Elgar, 2014, p. 334.

30 BEUNEN, Annemarie Christiane. Protection for databases The European Database Directive and its effects in the Netherlands, France and the United Kingdom [online]. Nijmegen: Wolf Legal Publishers, Nijmegen E.M. Meijers Institute of Legal Studies, Faculty of Law, Leiden University, 2007, p. 28.

31 RIEGER, Sören. Der rechtliche Schutz wissenschaftlicher Datenbanken. Tübingen: Mohr Siebeck, 2010, p. 129.

32 Ibid., p. 130.

33 DERCLAYE, Estelle. The Legal Protection of Databases A Comparative Analysis. Cheltenham, UK; Northampton, MA: Edward Elgar, 2008, p. 51. 
in The British Horseracing Board and Others. ${ }^{34}$ As regards the scope of the extraction right the CJEU concluded in the Directmedia Publishing ${ }^{35}$ case that it should not be limited only to physical copying of the extracted data. Even mere transfer following an on-screen consultation and an individual assessment of a database's content can constitute an infringement. The neutral term "re-utilization" covers any act of exploitation of the whole or a substantial part of the contents of the database in any form targeted at public. An operation of a meta-search engine that makes the whole or substantial parts of the database openly available to the public was also considered as an infringement of the re-utilization right. ${ }^{36}$

These sui generis rights of the maker of database are granted if the

"obtaining, verification or presentation of the contents"37

of the database represent a qualitative or quantitative substantial investment. An interpretation of these terms is crucial for granting of the sui generis protection and the CJEU ruled in its case law on the issues of what kind of investments are necessary to be taken into account when determining the substantial investment.

An investment in obtaining of the database can be understood either broadly or narrowly. The doctrine of spin-off databases that originated in the Netherlands could be regarded as the former approach. $^{38}$ Eventually the latter, i.e. narrow, interpretation prevailed (and currently still dominates) $^{39}$ the discourse. This approach is based mainly in the wording of recitals 19 and $39 .{ }^{40}$ A strict separation of the investment in the obtaining of the database/elements

34 The British Horseracing Board and Others, ECLI:EU:C:2004:695, C-203/02, para. 51.

35 Directmedia Publishing, C-304/07, ECLI:EU:C:2008:552.

36 Innoweb, C-202/12, ECLI:EU:C:2013:850.

For the analysis of this case see e.g.: HUSOVEC, Martin. End of (Meta) Search Engines in Europe, The. Chicago-Kent Journal of Intellectual Property. 2014, Vol. 14, Nr. 1.;

VIRTANEN, Perttu. Innoweb v Wegener: CJEU, Sui Generis database right and making available to the public - The war against the machines. European Journal of Law and Technology [online]. 2014, Vol. 5, Nr. 2 [cit. 30. 8. 2016].

37 Art. 7.

38 See e.g. HUGENHOLTZ, P. Bernt. Program Schedules, Event Data and Telephone Subscriber Listings under the Database Directive - The 'Spin-Off' Doctrine in the Netherlands and elsewhere in Europe. In: Eleventh Annual Conference on International IP Law \& Policy [online]. New York. 2003.

39 The British Horseracing Board and Others, ECLI:EU:C:2004:695, C-203/02, para. 33; Oy Veikkaus Ab, C-46/02, ECLI:EU:C:2004:694, para. 36; Svenska Spel AB, C-338/02, ECLI:EU:C:2004:696, para. 26; OPAP, C-444/02, ECLI:EU:C:2004:697, para. 42. 
and of generating/creating of the individual elements (data) was constructed in the case law of the CJEU. Accordingly, the purpose of the Directive is not to grant protection to individual elements or an investment into creation of those elements, but "databaseness" - or as it was explicitly expressed in The British Horseracing Board and Others - to

"promote the establishment of storage and processing systems for existing information and not the creation of materials capable of being collected subsequently in a database." 41

In the past, the CJEU ruled that the investment in the acquisition of the football fixture lists is a contribution to the obtaining of the contents of the database rather than an investment in obtaining of the database itself. $^{42}$ Finding and obtaining such data is inseparably linked to direct creation of the data, so it is not possible to speak of separable investments in arrangement of the created elements into a database - respectively such database will not be eligible for protection via sui generis rights of the maker of the database. The CJEU reached the same conclusion as regards to examination of databases of racehorses admitted to a particular race. ${ }^{43}$ The assessment whether a horse meets the conditions of participation equals effectively to creation of data and the costs incurred cannot be functionally separated from the cost of the creation of the database. ${ }^{44}$ Consequently, databases containing data generated solely by the producer of the database as by-product of his main activity ("sole-source databases") are not to be protected by sui generis rights. However, the CJEU states that there is no obstacle that would make it impossible for data producers to achieve the threshold needed for granting of the sui generis rights protection. The makers must demonstrate that the obtaining, verification or presentation of the elements constitutes a substantial investment that would be separable from sources utilized to create (generate) them. ${ }^{45}$ The most frequent methods of arrangement, i.e. chronological or alphabetical, could not be regarded as substantial

40 DERCLAYE, Estelle. Database Directive. In: STAMATOUDI, Irini A.; TORREMANS, Paul (eds.). EU Copyright Law: A Commentary. Cheltenham: Edward Elgar, 2014, p. 323.

${ }^{41}$ The British Horseracing Board and Others, ECLI:EU:C:2004:695, C-203/02, paras. 31-32. Also OPAP, C-444/02, ECLI:EU:C:2004:697, para. 40.

42 OPAP, C-444/02, ECLI:EU:C:2004:697, Svenska Spel AB, C-338/02, ECLI:EU:C:2004:696 and Oy Veikkaus Ab, C-46/02, ECLI:EU:C:2004:694.

${ }^{43}$ The British Horseracing Board and Others, C-203/02, ECLI:EU:C:2004:695, para. 38.

44 Ibid. 
investment and thus the obtaining by creating the data is not eligible to ground a "databaseness" that could be protected. ${ }^{46}$ The separable investment will only be possible when the data is created in an unarranged way and subsequent costs will incur with its obtaining or presentation. Derclaye claims that this restrictive approach shall contribute to the openness of the market and avoid the dominance of subjects who are generating specific types of data and amassing them in the so-called sole-source databases. ${ }^{47}$ In the "database tetralogy"48 the CJEU mitigated risks of overprotection of sole synthetic data generated and consequently available only from the database manager. ${ }^{49}$ Investment in the obtaining of the contents of the database thus must be understood as referring to the

"resources used to refer to the resources used to seek out existing independent materials and collect them in the database, and not to the resources used for the creation as such of independent materials". ${ }^{50}$

Other forms of investment apart from the funds directly associated with the obtaining of the database are not relevant. ${ }^{51}$ In the context of this paper it is important to note, that Ryanair's database of flights data is a typical example of such a solo-source database. The data generated solely by Ryanair are a by-product of operating airlines and the substantial investment does not subsist in obtaining the database. ${ }^{52}$ Furthermore, these

45 Concurring OPAP, C-444/02, ECLI:EU:C:2004:697, paras. 45-46; Svenska Spel AB, C-338/02, ECLI:EU:C:2004:696, paras. 29-30. The opposite view was presented in the Opinion of the Advocate General in the case Oy Veikkaus Ab, C-46/02, ECLI:EU:C:2004:332, para. 69.

46 DERCLAYE, Estelle. The Legal Protection of Databases A Comparative Analysis. Cheltenham, UK; Northampton, MA: Edward Elgar, 2008, p. 95.

47 Ibid., p. 96.

48 This term was coined for the cases The British Horseracing Board and Others, ECLI:EU:C:2004:695C-203/02; OPAP, C-444/02, ECLI:EU:C:2004:697; Svenska Spel AB, C-338/02, ECLI:EU:C:2004:696 and Oy Veikkaus Ab, C-46/02, ECLI:EU:C:2004:694 by Borghi and Karapapa in BORGHI, Maurizio; KARAPAPA, Stavroula. Contractual restrictions on lawful use of information: sole-source databases protected by the back door? European Intellectual Property Review. 2015, Vol. 37, Nr. 8, footnote 6 therein.

49 BORGHI, Maurizio; KARAPAPA, Stavroula. Contractual restrictions on lawful use of information: sole-source databases protected by the back door? European Intellectual Property Review. 2015, Vol. 37, Nr. 8, p. 505.

50 The British Horseracing Board and Others, ECLI:EU:C:2004:695, C-203/02, paras. 31-32; OPAP, C-444/02, ECLI:EU:C:2004:697, para. 41; Oy Veikkaus Ab, C-46/02, ECLI:EU:C:2004:694, para. 41 and Svenska Spel AB, C-338/02, ECLI:EU:C:2004:696, paras. 24-25.

51 E.g. the costs of upkeep of the database. See: NETTLETON, Ewan. Poetic justice for owners of database right. Journal of Database Marketing \& Customer Strategy Management [online]. 2009, Vol. 16, Nr. 1, p. 58.

52 Analogically to The British Horseracing Board and Others, C-203/02, ECLI:EU:C:2004:695 and OPAP, C-444/02, ECLI:EU:C:2004:697, Svenska Spel AB, C-338/02, ECLI:EU:C:2004:696 and Oy Veikkaus Ab, C-46/02, ECLI:EU:C:2004:694. 
data cannot be obtained freely, and are exclusively, by definition, generated and initially held by Ryanair.

The investment in verification refers, as stated by the CJEU, to the

"resources used, with a view to ensuring the reliability of the information

contained in that database, to monitor the accuracy of the materials collected when the database was created and during its operation". ${ }^{53}$

Correcting of duplicate records, eliminating typos and updating of the content shall ensure the reliability of the data in the long-term. ${ }^{54}$ The sole process of verification can be regarded as substantial investment even when the elements of the database do not change. Again the maker of the database must prove it is a substantial one in order to obtain the sui generis rights protection. ${ }^{55}$ It is also necessary to repeat that the costs of verification during creation cannot be included in the assessment of the substantiality of the investment. Consequently, the sui generis protection may arise only by verifying an existing dataset - it is not of importance however, whether it is a dataset directly produced (created) originally by the maker or obtained by other means.

An investment in presentation is, according to the CJEU case law, a reference to the data structure or organization as the way in which the elements are communicated to the user, $^{56}$ as well as references to resources that shall ensure the "function of processing information" 57 of the database. These are the resources used for

"systematic or methodical arrangement of the materials contained in that database and the organisation of their individual accessibility". ${ }^{58}$

This could include the creation of an index or thesaurus or of a nontrivial user interface. Derclaye further states that the presentation investment

\footnotetext{
Svenska Spel AB, C-338/02, ECLI:EU:C:2004:696, para. 27; Oy Veikkaus Ab, C-46/02, ECLI:EU:C:2004:694, para. 37.

54 DERCLAYE, Estelle. The Legal Protection of Databases A Comparative Analysis. Cheltenham, UK; Northampton, MA: Edward Elgar, 2008, p. 97.

55 DERCLAYE, Estelle. Database Directive. In: STAMATOUDI, Irini A.; TORREMANS, Paul (eds.). EU Copyright Law: A Commentary. Cheltenham: Edward Elgar, 2014, p. 325.

56 The British Horseracing Board and Others, ECLI:EU:C:2004:695C-203/02, para. 37.

57 Svenska Spel AB, C-338/02, ECLI:EU:C:2004:696, para. 27.

58 Ibid.
} 
could probably also include a transfer between media and the translation of the database. ${ }^{59}$

Surprisingly, very little guidance has been given by the CJEU on the issue of substantiality of the investment. ${ }^{60}$ The Directive itself does not provide for exact interpretive clues. ${ }^{61}$ The Directive only generally characterizes the nature of such investment in recital 7 where it states that

"the making of databases requires the investment of considerable human, technical and financial resources".

Recital 39 further speaks of "financial and professional investment" and finally recital 40 specifies that "investment may consist in providing funds and/or the expending of time, effort and energy". Thus the substantiality of the investment should be assessed ad hoc by the national courts.

Similarly as copyright, the sui generis rights are limited "vis-à-vis" the legitimate (lawful) ${ }^{62}$ user (Art. 8) of the database and for special purposes (Art. 9) ${ }^{63}$. The first limitation quite stipulates that extraction and re-utilization of non-substantial parts of the database do not constitute an infringement. Furthermore, the use of the publicly accessible database by a lawful user is still capped by the so-called three-step test. The optional exceptions (or rather limitations) may enable the lawful user ${ }^{64}$ of a database that has been made publicly available to extract or re-utilize a substantial part for private purposes, ${ }^{65}$ an illustration for non-commercial teaching and scientific research and for the public interest purposes. Also these

59 DERCLAYE, Estelle. The Legal Protection of Databases A Comparative Analysis. Cheltenham, UK; Northampton, MA: Edward Elgar, 2008, p. 98.

60 Frequently asked questions thus still include, e.g. whether the programming scripts for the purpose of presentation of the data constitutes substantial investment, to what extent the processing of source data (e.g. from questionnaires) into a statistic constitutes substantial investment statistics or whether anonymization of the data prior to publication could be regarded as investment substantial enough. In all cases, while undoubtedly an investment, it still remains questionable, whether it could be separated from the creation (generation) of the contents (e.g. in the case of electronic statistical processing of the paper questionnaires).

61 Derclaye deals extensively with the issue of "substantial investment" in: DERCLAYE, Estelle. Databases sui generis right: what is a substantial investment? A tentative definition. International Review of Intellectual Property and Competition Law. 2005, Vol. 36, Nr. 1.

${ }^{62}$ See the discussion of this term above in part 2.2.

63 GROSHEIDE, F. Willem. SUI Generis Protection for Databases the European way: An Analysis. International Intellectual Property Law E Policy. 2000, Vol. 4, p. 68-11.

${ }^{64}$ This quality of the beneficiary of the exception is not presupposed by the copyright limitations (Compare Art. 6(2)).

65 This exception covers only non-electronic databases. 
limitations must not be overridden by contract (Art. 15) and any arrangement among the parties to the contrary must be deemed null and void.

\subsection{PROTECTION OF UNPROTECTED DATABASES}

According to the Art. 13 the whole Directive is without prejudice to other types of legal protection. Consequently, databases (both protected by copyright and sui generis rights) can be also protected by contract. However, this applies also for the collection of data not meeting the criteria described above for granting protection by copyright/sui generis rights. The non-exhaustive list in Art. 13 comprises inter alia the law of contract, unfair competition protection or protection by technological protection measures pursuant Art. 6 of the InfoSoc Directive (32001L0029). ${ }^{66}$ In the analysis of the possibility of contractual protection of unprotected databases Derclaye differentiated the situation for the multi-source and sole-source databases. ${ }^{67}$ According to her, the former should not pose a legal problem, including the scrutiny based upon the competition law point of view. ${ }^{68}$ As the data is obtainable for everyone (i.e. they are substitutable), competition may exist despite the overprotective contract. ${ }^{69}$ In the case of sole-source databases, according to Derclaye the issues need a more granulated approach, as the nature of the contract is also of importance. ${ }^{70}$ A contract that is negotiated individually by the potential user of the data accessible in the sole-source database is not overprotective, as any other third party can (theoretically) copy the data, as no other protection exists. ${ }^{71}$ A contract of adhesion binding also subsequent third parties $^{72}$ would create a layer of protection that is akin to the protection

${ }^{66}$ DERCLAYE, Estelle. Database Directive. In: STAMATOUDI, Irini A.; TORREMANS, Paul (eds.). EU Copyright Law: A Commentary. Cheltenham: Edward Elgar, 2014, p. 347.

For critical discussion of DRM implications see e.g.: DUSOLLIER, Séverine. Tipping the Scale in Favor of the Right Holders: The European Anti-Circumvention Provisions. In: BECKER, Eberhard et al. (eds.). Digital Rights Management: Technological, Economic, Legal and Political Aspects. Berlin; New York: Springer, 2003.

67 DERCLAYE, Estelle. An Economic Analysis of the Contractual Protection of Databases. University of Illinois Journal of Law, Technology \& Policy. Vol. 2005, Issue 2 (Fall 2005), p. 267.

68 Ibid.

${ }^{69}$ Ibid., p. 266-267.

70 Ibid., p. 267.

71 Ibid.

72 Derclaye remarks that these-take-it-or-leave-it contracts often also bind subsequent users of the information products. Ibid., p. 259. 
granted pursuant the Directive. ${ }^{73}$ Such a possibility to actually create a "private legislation"74 and parallel protection regime leads to monopolisation of raw data. ${ }^{75}$ Derclaye critically notes, that in such scenario the manager of the sole-source database is basically rewarded for an investment they have not made and that such an unlimited contractual protection of otherwise unprotected databases is actually against the main policy objective of the Directive. ${ }^{76}$

\section{RYANAIR CASE}

The Ryanair case focused on a new perspective in protecting databases in the European Union. Whereas the years before Ryanair could be characterised as eloquent jurisprudential development and fine tuning of the respective terms in the Directive, ${ }^{77}$ in this case the CJEU newly focused on a the limits of contractual protection of databases unprotected by copyright or sui generis database rights.

The decision was met with strong criticism in the jurisprudence - Bottis goes as far as proclaiming that the Ryanair decision leaves

"the Directive just 'out of the matter", whereas it effectively negates its whole existence and subtracts from it any meaning at all". ${ }^{78}$

In order to evaluate such strong claim we should first briefly describe the case ${ }^{79}$ itself and then, in the next part, analyse the possible consequences of the CJEU decision.

In this dispute between Ryanair Ltd. and PR Aviation the defendant company offered on its web site a search, comparison and booking of low-cost flights of different airlines, among others also Ryanair's. The data for these services were obtained in an automated manner

73 Ibid, p. 268.

74 Ibid., p. 267-268.

75 HUGENHOLTZ, P. Bernt. Abuse of Database Right: Sole-source information banks under the EU Database Directive. In: Antitrust, Patent and Copyright [online]. 2004, p. 9.

${ }^{76}$ I.e. "investment in modern information storage and processing systems" (recital 12). DERCLAYE, Estelle. An Economic Analysis of the Contractual Protection of Databases. University of Illinois Journal of Law, Technology \& Policy. Vol. 2005, Issue 2 (Fall 2005), p. 258.

77 As shortly described above in part 2 of this paper.

78 BOTTIS, Maria. How Open Data Become Proprietary in the Court of Justice of the European Union. In: KATSIKAS, Sokratis K.; SIDERIDIS, Alexander B. (eds.). E-Democracy - Citizen Rights in the World of the New Computing Paradigms [online]. Switzerland: Springer International Publishing, 2015, p. 173 [cit. 30. 8. 2016].

79 See also: MYSOOR, Poorna. Protecting the unprotected database. The Law Quarterly Review. 2015, Vol. 131, Nr. 4. 
and from a data file which was connected to the website of Ryanair. The access to these websites and their use by visitors were subject to specific terms and conditions. These were presented visibly and the visitor needed to agree with them by checking the appropriate box. Among other terms, these reserved the right to sell tickets exclusively to Ryanair. Also, these general terms and conditions prohibited

"[t]he use of automated systems or software to extract data from this website or www.bookryanair.com for commercial purposes, ('screen scraping') [...] unless the third party has directly concluded a written licence agreement with Ryanair in which permits it access to Ryanair's price, flight and timetable information for the sole purpose of price comparison" ${ }^{80}$

In the national proceeding, the first instance, the District Court of Utrecht (Rechtbank Utrecht) denied Ryanair's claim on infringement of the Ryanair's sui generis database rights as it had not been able to prove existence of a substantial investment. ${ }^{81}$ On the other hand, the same court ruled that PR Aviation infringed the Ryanair's rights based on the Art. 10(1) of the Dutch Copyright Act granting protection to "all other writings". 82 The Court of Appeal of Amsterdam (Gerechtshof te Amsterdam) concurred on the absence of sui generis database rights. ${ }^{83}$ Further, it noted, that the activity of PR Aviation could be regarded as legitimate and normal use of the website even in the case of existence of the "all other writings" protection, that is allowed by the exception in Art. 24a(1) Dutch Copyright

80 BORGHI, Maurizio; KARAPAPA, Stavroula. Contractual restrictions on lawful use of information: sole-source databases protected by the back door? European Intellectual Property Review. 2015, Vol. 37, Nr. 8, p. 506.

As critically noted by Vousden, the CJEU did not focus at all on the issue consenting to the terms and conditions by PR Aviation. Despite denying the consent during the national proceedings, the defendant's consent was presupposed due to Dutch procedural law. VOUSDEN, Stephen. Autonomy, comparison websites, and Ryanair. Intellectual Property Quarterly. 2015, Vol. 19, Nr. 4, p. 392.

81 BORGHI, Maurizio; KARAPAPA, Stavroula. Contractual restrictions on lawful use of information: sole-source databases protected by the back door? European Intellectual Property Review. 2015, Vol. 37, Nr. 8, p. 506.

82 Vousden notes that this provision (in connection with the Art. 10(1)(4) Dutch Copyright Act) provides for "catch-all" protection for databases not protected specifically by copyright/sui generis database rights: i.e. "[...] to grant any database that fails to qualify for the EU law requirement of being a database with "a substantial investment" the right of legal protection in Dutch copyright law under the phrase "all other writings". VOUSDEN, Stephen. Autonomy, comparison websites, and Ryanair. Intellectual Property Quarterly. 2015, Vol. 19, Nr. 4, p. 390.

83 Ryanair, C-30/14, EU:C:2015:10, para. 21. 
Act. $^{84}$ This exception basically correspondents to the Art. 15 (of the Directive). ${ }^{85}$ After another appeal the Netherlands Supreme Court (Hoge Raad der Nederlanden) confirmed the absence of sui generis rights. However it had its doubt about the applicability of the exception pursuant Art. 24a(1) Dutch Copyright Act to databases that had not acquired neither copyright, nor sui generis database rights protection. ${ }^{86}$ The referring court stayed the proceedings and questioned the CJEU whether the operation of the Directive also extended

"to online databases which are not protected by copyright on the basis of Chapter II of the Directive, and also not by a sui generis right on the basis of Chapter III, in the sense that the freedom to use such databases through the (whether or not analogous) application of Articles 6(1) and 8 in conjunction with Article 15 [of the Database Directive], may not be limited contractually". ${ }^{87}$

The logic behind this rather cryptic question is simple. The above discussed limitations in Articles 6 and 8 the Directive introduce a certain level of minimal usage "rights" (exceptions to the exclusive rights) that are characterized as ius cogens. ${ }^{88}$ Consequently, a lawful user of the copyrighted database is entitled to reproduce, alter, distribute and communicate to the public if

"it is necessary for the purposes of access to the contents of the databases and normal use of the contents by the lawful user". ${ }^{89}$

\footnotetext{
${ }^{84}$ BORGHI, Maurizio; KARAPAPA, Stavroula. Contractual restrictions on lawful use of information: sole-source databases protected by the back door? European Intellectual Property Review. 2015, Vol. 37, Nr. 8, p. 506.

85 Ryanair, C-30/14, EU:C:2015:10, para. 22.

86 Ibid. Art. 24a(1) of the Dutch Copyright Act 1912 is explained in Ryanair, C-30/14, EU:C:2015:10, para. 21.

87 As critically noted by Vousden the CJEU re-phrased the question (Ryanair, C-30/14, EU:C:2015:10, para. 29), as to whether the freedom to use a database within the meaning of Article 1(2) of Directive 96/9 that however does not fulfil the requirements for protection neither by copyright, nor by sui generis database rights might be contractually limited or not. VOUSDEN, Stephen. Autonomy, comparison websites, and Ryanair. Intellectual Property Quarterly. 2015, Vol. 19, Nr. 4, p. 390.

88 HUGENHOLTZ, P. Bernt. Database Directive. In: DREIER, Thomas et al. (eds.). Concise European Copyright Law. Alphen aan den Rijn: Kluwer Law International, 2006, p. 340.

89 Art. 6(1).
} 
Further the maker of the database protected by sui generis rights that has been made publicly available in whatever manner, may not prevent a lawful user of the database

"from extracting and/or re-utilizing insubstantial parts of its contents, evaluated qualitatively and/or quantitatively, for any purposes whatsoever". ${ }^{90}$

Pursuant to the Art. 15 these specific limitations must not be contracted out. $^{91}$ The absence of such protection will rule out any statutory limitation and would leave the unprotected "bare" database at contractual stake of the manager" of such synthetic data.

Without consulting the Advocate General's Opinion the CJEU followed this "bare database contractual protection" concept ${ }^{93}$ and ruled that

"it is clear from the purpose and structure of Directive 96/9 that Articles 6(1), 8 and 15 thereof, which establish mandatory rights for lawful users of databases, are not applicable to a database which is not protected either by copyright or by the sui generis right under that directive, so that it does not prevent the adoption of contractual clauses concerning the conditions of use of such a database."

90 Art. 8(1).

91 According to Derclaye, a contrario other limitations and exceptions (e.g. the optional stipulated in Art. 9) might be contractually overridden. See: DERCLAYE, Estelle. Database Directive. In: STAMATOUDI, Irini A.; TORREMANS, Paul (eds.). EU Copyright Law: A Commentary. Cheltenham: Edward Elgar, 2014, p. 352.

92 Bottis quite aptly asks whether it is even appropriate to use the terms "author"/"maker" for persons controlling such databases. BOTTIS, Maria. How Open Data Become Proprietary in the Court of Justice of the European Union. In: KATSIKAS, Sokratis K.; SIDERIDIS, Alexander B. (eds.). E-Democracy - Citizen Rights in the World of the New Computing Paradigms [online]. Switzerland: Springer International Publishing, 2015, p. 173 [cit. 30. 8. 2016].

93 As Bottis noted: "And the Court of Justice of the European Union agreed: as if William Hill/British Horseracing Board and Football DataCo had never existed, it "threw" the whole case out of the intellectual property rules of databases and confined it into another field: contract." BOTTIS, Maria. How Open Data Become Proprietary in the Court of Justice of the European Union. In: KATSIKAS, Sokratis K.; SIDERIDIS, Alexander B. (eds.). E-Democracy - Citizen Rights in the World of the New Computing Paradigms [online]. Switzerland: Springer International Publishing, 2015, p. 172 [cit. 30. 8. 2016].

Similarly GUPTA, Indranath; DEVAIAH, Vishwas H. The Database Directive "contracting out" bar: does it apply to unprotected databases? Journal of Intellectual Property Law $\mathcal{E}$ Practice [online]. 2015, Vol. 10, Nr. 9.

${ }^{94}$ Ryanair, C-30/14, EU:C:2015:10, para. 39. 
A mere fulfilling of the conceptual features database ${ }^{95}$ does not automatically give rise to any of the two tiers of protection. Consequently, the Directive does not

"preclude the author of such a database from laying down contractual limitations on its use by third parties". ${ }^{96}$

Further, where the Directive is not applicable,

"its author [sic!] is not eligible for the system of legal protection instituted by that directive, so that he may claim protection for his database only on the basis of the applicable national law". ${ }^{97}$

\section{CONSEQUENCES OF THE RYANAIR DECISION}

The simplistic conclusion from the Ryanair case is that less is indeed more. In order to obtain a protection without any (mandatory) exceptions and limitations, it is now, on the first glance, more favourable not to fulfil the pre-requirements for copyright or sui generis protection granted by the Directive and rely on other protection regimes, as discussed above. ${ }^{98}$

On the other hand, the court could have had hardly decided differently. The answer provided by the CJEU merely follows the strikingly simple logic, namely that the issue pertaining to non-regulated issues is also not regulated by the Directive. Or as the CJEU directly expressed it:

"[...] Articles 6(1), 8 and 15 of Directive 96/9, which confer rights on lawful users and, in so doing, limit those of the person who created the database, are applicable only in respect of a database over which its author has rights to title, either copyright in Article 5 of that directive or the sui generis right in Article 7 thereof. However, it is irrelevant with regard to a database whose author does not enjoy any of the abovementioned rights under Directive 96/9." 99

As a result, as Consonni and Anselmi put it, the unprotected database is "technically an immaterial asset to which the Directive simply does not apply"

95 Art. 1(2) Directive: 'database' shall mean a collection of independent works, data or other materials arranged in a systematic or methodical way and individually accessible by electronic or other means.

96 Ryanair, C-30/14, EU:C:2015:10, para. 45.

97 Ibid., para. 44.

98 The Directive and regulation therein is without prejudice other means of protection of databases that are demonstratively enumerated entailed in the Art. 13.

99 Ryanair, C-30/14, EU:C:2015:10, para. 40. 
and subsequently the provisions of the Directive "are not binding to any party". ${ }^{100}$ Thus the contractual freedom of the manager of the (unprotected) database is not limited by the Directive. ${ }^{101}$ In the end the Ryanair is actually not a case about copyright and sui generis database rights, but about contract law. As noted by Czychowski, the CJEU said something for the first time what could be contracted about and what are the applicable limits of such contract. ${ }^{102}$ It raises interesting questions stemming mainly from what has not been said by the CJEU, rather than from the straightforward answer to the question referred.

The first set of issues concerns the existence of protection regimes as such and a disposition therewith. In the light of the Ryanair case, the most basic question is whether it is possible to simply state that the protection regimes do not apply and thus exclude them even though a substantial investment has been made or the arrangement is original enough for obtaining copyright protection. In our opinion, such a deconstruction of the protection is not possible as this is a questio iuris to be decided by the respective national court in a dispute and not by contract among the parties. However, the negative consequence may be that the creators and makers of databases would gamble (quite perversely indeed) on not achieving the desired threshold in order not to obtain the foreseen protection and thus to be able to fully realize their private autonomy by contractual protection unlimited by the exceptions and limitations set in the Directive. Such a consequence would severely undermine the desired aim of the protection envisaged by the Directive, i.e. to stimulate "investment in modern information storage and processing systems" (recital 13).

A closely connected issue is the counterpart of the above-presented idea. Namely, whether the databases that are exempted from the protection ${ }^{103}$ can

${ }^{100}$ CONSONNI, Marco; ANSELMI, Ludovico. ECJ rules on screen-scraping of Ryanair's database. E-Commerce Law and Policy. 2015, Vol. 17, Nr. 2, p. 7.

101 This conclusion is heavily criticized by Borghi and Karapa, who claim that that the limits imposed on the copyright or sui generis rights protected databases should be also applicable to any database that meets definition in Art 1(2). BORGHI, Maurizio; KARAPAPA, Stavroula. Contractual restrictions on lawful use of information: sole-source databases protected by the back door? European Intellectual Property Review. 2015, Vol. 37, Nr. 8, p. 511.

102 CZYCHOWSKI, Christian. EUGH: Keine Anwendung der Vertragsbeschränkungen der Datenbank-RL auf nicht geschützte Datensammlung - Ryanair/PR Aviation. Gewerblicher Rechtsschutz und Urheberrecht. 2015, Vol. 117, Nr. 3, p. 255.

103 E.g. official state databases as is the case in Czech Republic. Pursuant to the $\S 3$ Czech Copyright Act such databases are exempted from copyrigt protection. Pursuant to the the latest amendment to $\S 94$ Czech Copyright Act such official state databases shall be exempted also from the sui generis database rights protection. 
be protected solely by contract? Here again we are observing the rather paradoxical consequences of this decision. Following the Ryanair logic these "databases" could be indeed protected by contract inter partes. The public interest exceptions are tailored to databases that would be otherwise protected. However, if no protection regime applies and no protection exists, there is no subject matter that could be protected and consequently excluded (i.e. no exception applies). Unluckily, as Bottis remarks cum grano salis, this is the "wrong side of the 'outside"". ${ }^{104}$ Again, quite surprisingly, for the potential screen scraper it would be favourable if the protection was established in the respective national proceeding as he could then rely on the exception that cannot be overridden by contract.

However, the contract itself is not a panacea or a penultimate protection. Even if the formed contract is enforceable (which could also be debated under the respective national law), another set of problems arises from the fact that the contract is effective only inter partes. Thus if the party scraping the content breaches the contract and makes contents of the unprotected database available online, third parties may make use of it without infringing any absolute rights to data. ${ }^{105}$ As was already mentioned, it will depend on the national law whether the contract (or its parts) would stand in court and deemed enforceable or regarded as unfair and thus null and void. ${ }^{106}$ This particularization leads as to further negative and paradoxical consequence of the Ryanair case namely further disintegration of the common market as the contractual law is not harmonized. ${ }^{107}$

Finally, the decision raises another, more general civil law questions. A prime example being the underlying issue of what is the object of the contract. That is what absolute rights to data (in rem) are to be

${ }^{104}$ BOTTIS, Maria. How Open Data Become Proprietary in the Court of Justice of the European Union. In: KATSIKAS, Sokratis K.; SIDERIDIS, Alexander B. (eds.). E-Democracy - Citizen Rights in the World of the New Computing Paradigms [online]. Switzerland: Springer International Publishing, 2015, p. 173, [cit. 30. 8. 2016].

${ }^{105}$ SYNODINOU, Tatiana. Ryanair Ltd v. PR Aviation BV: contracts, rights and users in a "low cost" database law. Kluwer Copyright Blog [online]. 26. 1. 2015 [cit. 30. 8. 2016].

${ }^{106}$ For examples of different national treatment see: BORGHI, Maurizio; KARAPAPA, Stavroula. Contractual restrictions on lawful use of information: sole-source databases protected by the back door? European Intellectual Property Review. 2015, Vol. 37, Nr. 8, p. 512513.

${ }^{107}$ Czychowski asks, whether the CJEU goes beyond his competence when deciding about a question that cannot be a part of the preliminiary question (Art. 267 TFEU). CZYCHOWSKI, Christian. EUGH: Keine Anwendung der Vertragsbeschränkungen der Datenbank-RL auf nicht geschützte Datensammlung - Ryanair/PR Aviation. Gewerblicher Rechtsschutz und Urheberrecht. 2015, Vol. 117, Nr. 3, p. 253. 
relativized by the contract itself. The Ryanair decision opened up an issue that should be completely out of scope of the Directive and also for the EU does not have enough competence to regulate, namely the property protection for mere data. ${ }^{108}$ If no such rights are acknowledged by the national legislator, the access to data itself can probably only be offered as a service. However, this claim and related rationale has to be explored in further research.

In the light of the above described issues the question is, whether these could be mitigated and if yes, then how. Given the answer of the CJEU, the "analogous" application of the Art 15 to unprotected databases, as proposed by is simply not possible. As there is no protected subject matter, the concept of lawful user and its usage rights (exceptions) simply do not come into play at all. As was already mentioned, the solution must be therefore found on the national level, namely in the contract and competition law. Regarding the former area, the "overprotective" contracts could be deemed unfair. The only EU Directive ${ }^{109}$ (resp. its national transpositions) in this area is however inapplicable as it deals only with the consumer contracts and not intellectual property. ${ }^{110}$ Therefore, the potential commercial web scraper would have to try find other leeway. As possible solution lies even one logical step before the already discussed topics, that is a negation of the contract itself. In the Spanish case Ryanair Ltd $v$ Atrapálo SL the Supreme Tribunal ruled that the commercial web scraper did not enter into any contract and thus did not breach the conditions prohibiting web scraping. ${ }^{111}$ In Germany, the activities of a web scraper who did not respect the restrictions in terms

${ }^{108}$ Lately, this issue has taken up in importance in the jurisprudence, especially in Germany. See e.g.: HOEREN, Thomas. Dateneigentum: Versuch einer Anwendung von §303a StGB im Zivilrecht. MultiMedia und Recht. 2013, Vol. 16, Nr. 8.; ZECH, Herbert. Information as Property. Journal of Intellectual Property, Information Technology and Electronic Commerce Law. [online]. 2015, Vol. 6, Nr. 3.

109 31993L0013.

${ }^{110}$ BORGHI, Maurizio; KARAPAPA, Stavroula. Contractual restrictions on lawful use of information: sole-source databases protected by the back door? European Intellectual Property Review. 2015, Vol. 37, Nr. 8, p. 513.

111 Ryanair Ltd v Atrapálo SL, Tribunal Supremo, Senencia n. 572/2012. However, in Ireland, the Irish High Court reached an opposite conclusion. Ryanair Ltd v Billigfluege.de GmbH [2010] IEHC 47. Overview of the case law is provided in: BORGHI, Maurizio; KARAPAPA, Stavroula. Contractual restrictions on lawful use of information: sole-source databases protected by the back door? European Intellectual Property Review. 2015, Vol. 37, Nr. 8, p. 512513. 
and conditions imposed by Ryanair did not per se constitute an act of unfair competition. $^{112}$

In the latter area (competition law), the contractual monopolization could be regarded as abuse of the dominant position of the manager of the sole-source database pursuant to the national competition law. In 2013 the Court of Milan held that the refusal of access to the Ryanair's database for a travel agency is to be regarded as an abuse of dominant position in the downstream market of information and intermediation of flights. ${ }^{113}$ Hugenholtz proposed a possible solution to such situation, namely the obligation of the sole-source database managers to provide the exclusive data under fair and reasonable conditions. ${ }^{114}$ A detailed discussion of such a regulatory scheme however is out of scope of this article and has been identified as a further potential area of research. As this solution would differ from the "compulsory licensing scheme" that was meant to be introduced in the Directive, ${ }^{115}$ the issues to be tackled would be the EU competence to legislate on these issues.

\section{CONCLUSION}

During the twenty years of existence of the Directive the CJEU tried to explain and elaborate on the meaning of the two-tier protection and find the correct equilibrium ${ }^{116}$ and

112 HUSOVEC, Martin. BGH: Screen Scraping Does Not Constitute Unfair Competition. Hut'ko's Technology Law Blog [online]. 30. 4. 2014 [cit. 30. 8. 2016].

${ }^{113}$ Decision of June 4, 2013 Viaggiare S.r.l. vs Ryanair Ltd. Commented in: DE SANTIS, Frederica. ECJ clarifies Database Directive scope in screen scraping case. The Global Legal Post [online]. 15. 3. 2016 [cit. 30. 8. 2016].

See for details and further case law: CONSONNI, Marco; ANSELMI, Ludovico. ECJ rules on screen-scraping of Ryanair's database. E-Commerce Law and Policy. 2015, Vol. 17, Nr. 2.

114 HUGENHOLTZ, P. Bernt. Abuse of Database Right: Sole-source information banks under the EU Database Directive. In: Antitrust, Patent and Copyright [online]. 2004, p. 9.

115 See for details of this system: HUGENHOLTZ, P. Bernt. Abuse of Database Right: Solesource information banks under the EU Database Directive. In: Antitrust, Patent and Copyright [online]. 2004, p. 4.;

BORGHI, Maurizio; KARAPAPA, Stavroula. Contractual restrictions on lawful use of information: sole-source databases protected by the back door? European Intellectual Property Review. 2015, Vol. 37, Nr. 8, p. 508.

116 E.g. by trying to limit the protection of sole-producers of databases. It could be however claimed that Ryanair means a somewhat modified resurrection of the spin-off theory valid inter partes. See: BOTTIS, Maria. How Open Data Become Proprietary in the Court of Justice of the European Union. In: KATSIKAS, Sokratis K.; SIDERIDIS, Alexander B. (eds.). E-Democracy - Citizen Rights in the World of the New Computing Paradigms [online]. Switzerland: Springer International Publishing, 2015, p. 173-174 [cit. 30. 8. 2016]. 
"balance between the rights of the person who created [sic!] a database and the rights of lawful users of such a database". ${ }^{117}$

By strengthening the position of the managers of unprotected databases significantly in the Ryanair decision, the CJEU seems to abandon such a search and designated the debate into the national context. Furthermore, the importance of contractual terms of use, a new layer of protection, has been confirmed as a relatively rigid mode of protection.

In 2005 Derclaye asked, whether sole-source databases unprotected by copyright/sui generis database rights can and, if so, should, be protected by contract. ${ }^{118}$ We can conclude and sum up the Ryanair case and this paper by stating that a decade later, the CJEU clearly answered the first part in the Ryanair case in the affirmative. As was predicted by Hugenholtz in 2006, the database managers are now able to "lock-up" their databases and potentially "abuse" the contract law to protect synthetic data. The answer to the second part, i.e. whether such contracts will be actually enforceable is consequently remanded to the national legislative solutions. Given the absence of harmonization in the field of contract and competition law in these questions, the Ryanair decision might lead to re-fragmentation of the internal market. ${ }^{119}$ A more structural solution, rather than individual national ad hoc judgements, is now more advisable than ever. One option, that was identified as a potential area of further research, would be the obligation of the sole-source database managers to provide the exclusive data under fair and reasonable conditions. ${ }^{120}$ Without such a solution reliance on a strong contractual protection of unprotected databases could lead to monopolization of the market of information and "negative effects on competition". ${ }^{121}$

Painting with a broad brush the decision raises also the question of what is actually (not) protected by the Directive, by what means and whether

${ }_{117}$ Ryanair, C-30/14, EU:C:2015:10, para. 40.

${ }^{118}$ DERCLAYE, Estelle. An Economic Analysis of the Contractual Protection of Databases. University of Illinois Journal of Law, Technology \& Policy. Vol. 2005, Issue 2 (Fall 2005), p. 247.

119 BORGHI, Maurizio; KARAPAPA, Stavroula. Contractual restrictions on lawful use of information: sole-source databases protected by the back door? European Intellectual Property Review. 2015, Vol. 37, Nr. 8, p. 507.

${ }^{120}$ As proposed by Hugenholtz in: HUGENHOLTZ, P. Bernt. Abuse of Database Right: Solesource information banks under the EU Database Directive. In: Antitrust, Patent and Copyright [online]. 2004, p. 9.

${ }^{121}$ BORGHI, Maurizio; KARAPAPA, Stavroula. Contractual restrictions on lawful use of information: sole-source databases protected by the back door? European Intellectual Property Review. 2015, Vol. 37, Nr. 8, p. 512. 
such a protection is necessary. After Ryanair, one could actually argue whether (at least) the sui generis protection is indeed needed or not, when the contractual layer could theoretically suffice. The proposed the withdrawal of the sui generis rights protection presented in the Evaluation report of the Directive ${ }^{122}$ thus got a new legal impulse for reconsideration. ${ }^{123}$

\section{LIST OF REFERENCES}

BEUNEN, Annemarie Christiane. Protection for databases The European Database Directive and its effects in the Netherlands, France and the United Kingdom [online]. Nijmegen: Wolf Legal Publishers, Nijmegen E.M. Meijers Institute of Legal Studies, Faculty of Law, Leiden University, 2007 [cit. 30. 8. 2016]. Series of the E.M. Meijers Institute of Legal Studies of Leiden University, 125. ISBN 978-90-5850-267-4. Available from: https://openaccess.leidenuniv.nl/handle/1887/12038.

BORGHI, Maurizio; KARAPAPA, Stavroula. Contractual restrictions on lawful use of information: sole-source databases protected by the back door? European Intellectual Property Review. 2015, Vol. 37, Nr. 8, p. 505-514.

BOTTIS, Maria. How Open Data Become Proprietary in the Court of Justice of the European Union. In: KATSIKAS, Sokratis K.; SIDERIDIS, Alexander B. (eds.). E-Democracy - Citizen Rights in the World of the New Computing Paradigms [online]. Switzerland: Springer International Publishing, 2015, Communications in Computer and Information Science, 570, p. 169-174 [cit. 30. 8. 2016]. ISBN 978-3-319-27163-7.

${ }^{122}$ COMMISSION OF THE EUROPEAN COMMUNITIES. First Evaluation of Directive 96/9/EC on the Legal Protection of Databases [online]. Brussels: Commission of the European Communities. 2005, p. 23-26 [cit. 30. 8. 2016]. DG INTERNAL MARKET AND SERVICES WORKING PAPER.

${ }^{123}$ However, as aptly noted by Bygrave, any further research on the presented issues should be preceded by a proper discussion of the underlying meaning of basic information concepts in law such as data, information and database. BYGRAVE, Lee A. Information Concepts in Law: Generic Dreams and Definitional Daylight. Oxford Journal of Legal Studies [online]. 2015, Vol. 35, Nr. 1, p. 118-120. 
Available from: http://link.springer.com/chapter/10.1007/978-3-31927164-4_12.

BYGRAVE, Lee A. Information Concepts in Law: Generic Dreams and Definitional Daylight. Oxford Journal of Legal Studies. 2015, Vol. 35, Nr. 1, p. 91-120. DOI:10.1093/ojls/gqu011.

COMMISSION OF THE EUROPEAN COMMUNITIES. DG INTERNAL MARKET AND SERVICES WORKING PAPER: First Evaluation of Directive 96/9/EC on the Legal Protection of Databases [online]. Brussels: Commission of the European Communities 2005 [cit. 30. 8. 2016]. Available from: http://ec.europa.eu/internal_market/copyright/docs/ databases/evaluation_report_en.pdf.

CONSONNI, Marco; ANSELMI, Ludovico. ECJ rules on screen-scraping of Ryanair's database. E-Commerce Law and Policy. 2015, Vol. 17, Nr. 2, p. 5-7.

CZYCHOWSKI, Christian. EuGH: Keine Anwendung der Vertragsbeschränkungen der DatenbankRL auf nicht geschützte Datensammlung - Ryanair/PR Aviation. Gewerblicher Rechtsschutz und Urheberrecht. 2015, Vol. 117, Nr. 3, p. 253-256.

DAVISON, Mark J. The Legal Protection of Databases. Cambridge: Cambridge University Press, 2003, 358 p. ISBN 978-1-139-43565-9.

DERCLAYE, Estelle. An Economic Analysis of the Contractual Protection of Databases. University of Illinois Journal of Law, Technology $\mathcal{E}$ Policy. Vol. 2005, Issue 2 (Fall 2005), p. 247-272.

DERCLAYE, Estelle. Databases sui generis right: what is a substantial investment? A tentative definition. International Review of Intellectual Property and Competition Law. 2005, Vol. 36, Nr. 1, p. 2-30. 
DERCLAYE, Estelle. The Legal Protection of Databases A Comparative Analysis.

Cheltenham, UK; Northampton, MA: Edward Elgar, 2008. ISBN 978-184720-133-1.

DERCLAYE, Estelle. Database Directive. In: STAMATOUDI, Irini A.; TORREMANS, Paul (eds.). EU Copyright Law: A Commentary. Cheltenham: Edward Elgar, 2014, Elgar Commentaries, p. 298-354. ISBN 978-1-78195-242-9.

DE SANTIS, Frederica. ECJ clarifies Database Directive scope in screen scraping case. The Global Legal Post [online] b.n. 2016 [cit. 30. 8. 2016]. Available from: http://www.globallegalpost.com/blogs/global-view/ecjclarifies-database-directive-scope-in-screen-scraping-case-128701/.

DUSOLLIER, Séverine. Tipping the Scale in Favor of the Right Holders: The European Anti-Circumvention Provisions. In: BECKER, Eberhard et al. (eds.). Digital Rights Management: Technological, Economic, Legal and Political Aspects. Berlin; New York: Springer, 2003, Lecture Notes in Computer Science, 2770, p. 462-478. ISBN 3-540-40465-1.

GROSHEIDE, F. Willem. SUI Generis Protection for Databases the European way: An Analysis. International Intellectual Property Law $\mathcal{E}$ Policy. 2000, Vol. 4, p. 68-1-68-16.

GUPTA, Indranath; DEVAIAH, Vishwas H. The Database Directive "contracting out" bar: does it apply to unprotected databases? Journal of Intellectual Property Law E Practice. 2015, vol. 10, Nr. 9, p. 669-672. DOI:10.1093/jiplp/jpv127.

HERR, Robin Elizabeth. Is the Sui Generis Right a Failed Experiment: A Legal and Theoretical Exploration of How to Regulate Unoriginal Database Contents and Possible Suggestions for Reform. Copenhagen: DJØF Pub., 2008. ISBN 978-87-574-1881-1. 
HOEREN, Thomas. Dateneigentum: Versuch einer Anwendung von § 303a StGB im Zivilrecht. MultiMedia und Recht. 2013, Vol. 16, Nr. 8, p. 486-491. HUGENHOLTZ, P. Bernt. Program Schedules, Event Data and Telephone Subscriber Listings under the Database Directive - The 'Spin-Off' Doctrine in the Netherlands and elsewhere in Europe. In: Eleventh Annual Conference on International IP Law \& Policy [online]. New York. 2003 [cit. 30. 8. 2016]. Available from:

http://www.ivir.nl/publicaties/download/961.

HUGENHOLTZ, P. Bernt. Abuse of Database Right: Sole-source information banks under the EU Database Directive. In: Antitrust, Patent and Copyright [online]. 2004 [cit. 30. 8. 2016]. Available from: http://textlab.io/doc/9715910/abuse-of-database-right-sole-sourceinformation-banks.

HUGENHOLTZ, P. Bernt. Database Directive. In: DREIER, Thomas et al. (eds.). Concise European Copyright Law. Alphen aan den Rijn: Kluwer Law International, 2006, p. 307-342. ISBN 90-411-2384-9.

HUSOVEC, Martin. BGH: Screen Scraping Does Not Constitute Unfair Competition. Hut'ko's Technology Law Blog [online]. 2014. [cit. 30. 8. 2016]. Available from: http://www.husovec.eu/search/label/data\%20scraping. HUSOVEC, Martin. End of (Meta) Search Engines in Europe, The. ChicagoKent Journal of Intellectual Property. 2014, Vol. 14, Nr. 1, p. 145-172.

LEWINSKI, Silke von. Database Directive. In: WALTER, Michel M.; LEWINSKI, Silke von (eds.). European Copyright Law: A Commentary. Oxford; New York: Oxford University Press, 2010, p. 678-828. ISBN 9780-19-922732-7.

MYSOOR, Poorna. Protecting the unprotected database. The Law Quarterly Review. 2015, Vol. 131, Nr. 4, p. 556-562. 
MYŠKA, Matěj; KOŠČÍK, Michal. Controlling Data in Networked Research. In: Internationales Rechtsinformatik Symposion: Tagungsband des 19. Internationales Rechtsinformatik Symposions. Salzburg: Österreichische Computer Gesellschaft, 2016, p. 537-544. ISBN 978-3-903035-09-6.

NETTLETON, Ewan. Poetic justice for owners of database right. Journal of Database Marketing \& Customer Strategy Management. 2009, Vol.16, Nr. 1, p. 57-60. DOI:10.1057/dbm.2009.2.

QUAEDVLIEG, Antoon. Overlap/relationships between copyright and other intellectual property rights. In: DERCLAYE, Estelle (ed.). Research Handbook on the Future of EU Copyright. Cheltenham, UK: Northampton, MA: Edward Elgar, 2009, Research handbooks in intellectual property, p. 480-516. ISBN 978-1-84720-392-2.

RIEGER, Sören. Der rechtliche Schutz wissenschaftlicher Datenbanken. Tübingen: Mohr Siebeck, 2010, 336 p. ISBN 978-3-16-150377-1.

SYNODINOU, Tatiana. 20 years after the birth of the Database Directive, still mapping EU database law... Kluwer Copyright Blog [online]. 2015. [cit. 30. 8. 2016]. Available from:

http://kluwercopyrightblog.com/2015/12/15/20-years-after-the-birth-ofthe-database-directive-still-mapping-eu-database-law/.

SYNODINOU, Tatiana. Ryanair Ltd v. PR Aviation BV: contracts, rights and users in a "low cost" database law. Kluwer Copyright Blog [online]. 2015. [cit. 30. 8. 2016]. Available from:

http://kluwercopyrightblog.com/2015/01/26/ryanair-ltd-v-pr-aviation-bvcontracts-rights-and-users-in-a-low-cost-database-law/.

TROSOW, Samuel E. Sui Generis Database Legislation: A Critical Analysis. Yale Journal of Law and Technology. 2004, Vol. 7, Nr. 2, p. 534-642. 
VIRTANEN, Perttu. Innoweb v Wegener: CJEU, Sui Generis database right and making available to the public - The war against the machines. European Journal of Law and Technology. 2014, Vol. 5, Nr. 2, p. 1-10.

VOUSDEN, Stephen. Autonomy, comparison websites, and Ryanair. Intellectual Property Quarterly. 2015, Vol. 19, Nr. 4, p. 386-406.

$\mathrm{ZECH}$, Herbert. Information as Property. Journal of Intellectual Property, Information Technology and Electronic Commerce Law. 2015, Vol. 6, Nr. 3, p. 192-197. URN:NBN:DE:0009-29-43156. 